$\mathrm{X}$-ray studies were made on Hyderabad clays and on stilbene derivatives, and the conductivity of lithium nitrate in mixtures of methyl and ethyl alcohol and the isomerization of chromic chloride hexahydrate were studied in the Physical Chemistry Section. The Analytical Section is working out a method for the determination of tartaric acid with potassium dichromate, and a systematic study of the fusel oil from the Nizam sugar factory, Bodham, Hyderabad State, indicated that it contains 50 per cent of amyl alcohol with fair proportions of propyl and isopropyl alcohol. Besides erecting the lowtemperature carbonization plant, the Chemical Engineering Section determined the solubilities of groundnut oil in 98 per cent ethyl alcohol at $40-60^{\circ} \mathrm{C}$., while the Operational Research Unit was concerned with the manufacture of fructose on a semi-commercial scale, of triricinolein and of sesamin.

\section{OXFORD SYSTEM OF DECIMAL CLASSIFICATION FOR FORESTRY}

GOREST bibliography has for long been a difficult 4 subject to deal with, more especially since forestry research institutes and new forest departments and their resulting publications began to make their appearance. Certainly nowadays it would be almost impossible to keep au fait with the great output of forestry literature without some form of international classification.

The International Association of Forest Research Institutes-since 1929 called the International Union of Forest Research Organizations-had put the question of forest bibliography on its programme as early as 1903 with the object of creating a minimal system of classification and an international forest bibliography, the work being then entrusted to a Bibliographical Committee. The subject was discussed at the three international forestry congresses held in Rome (1926), Budepest and Helsinki. From the outset, the Swiss forester, Dr. Philipp Flury, was one of the most ardent workers in this new cause in preparation, and it was not until 1933 that the Committee presented to the International Union a complete system of classification of forest literature which was adopted in congress. It bore the title "Forest Bibliography", but became widely known as the "Flury System". It was assigned the decimal signature $634.9 \mathrm{~F}$, to distinguish it from the heading 634.9 forestry in the Universal Decimal Classification, which differs in the details of its sub-division. One of the Flury System's main uses was to classify the title references comprising the International Forest Bibliography-a scheme organized by the International Union for the regular exchange between member countries of references to literature considered to be of international importance.

The first post-war meeting of the Bibliographical Committee was held in Zurich in 1948 under the chairmanship of Prof. H. Burger. At this meeting Mr. F. C. Ford Robertson, director of the Commonwealth Forestry Bureau at Oxford, presented a completely revised system of classification for forest literature which had been prepared by his Bureau in consultation with the chief research station (Alice Holt) of the British Forestry Commission and the Forest Products Research Laboratory at Princes Risborough. This revision was based upon ten years of experience gained by the Bureau in the course of its day-to-day work in abstracting and classifying the world flow of forestry literature.

When a working agreement had been reached between the International Union of Forest Research Organizations and the United Nations Food and Agriculture Organization, the International Council of the former proposed to the latter the appointment of a joint Bibliographical Committee to study the new classification and to make appropriate recommendations to both. This was to supersede the previous Committee, and on it was appointed $\mathrm{A}$. Oudin, director of the Nancy Forestry School, F. C. Ford Robertson and E. Saari, professor of economics in the University of Helsinki. J. D. B. Harrison and R. G. Fontaine were appointed by the Food and Agriculture Organization. Meetings of the Com. mittee were held at Helsinki, Oxford, The Hague, Wageningen, Oxford and Rome. During this period the new classification system submitted by the Commonwealth Forestry Bureau at Oxford was carefully examined, and at various stages of revision was widely circulated to members of the International Union and research stations throughout the forestry world. Throughout the four years of revision, the Commonwealth Forestry Bureau acted as the natural clearing house for the work of correspondence and collation involved, in which Mr. P. G. Beak, assistant director of the Bureau, proved an invaluable helper.

The definitive English text of the new system of classification (which runs to 115 pages) is called the "Oxford System of Decimal Classification for Forestry"* and was finally presented to the International Congress in Rome in September 1953, when it was unanimously adopted with the recommendation that translations of the English text should be published in French, German and Spanish. The Food and Agriculture Organization, at its seventh session in Rome, approved of the system with a few resolutions on the subject of periodical revisions and so forth. E. P. Stebbing

* The Oxford System of Decimal Classiflcation for Forestry. (Reing the Deflnitive English Version as authorized by the Rome Congress of the International Union of Forest Research Organizations, September 1953, and published on their Behalf by the Commonwealth Agricultural Bureaux.) Pp. 115. (Farnham Royal: Commonwealth Agricultural Bureaux, 1954.) 10 s.

\section{SUBMARINE ILLUMINATION AND THE TWILIGHT MOVEMENTS OF A SONIC SCATTERING LAYER}

\section{By ELIZABETH M. KAMPA and BRIAN P. BODEN}

Scripps Institution of Oceanography, La Jolla, California

T has long been recognized that many zooplankton organisms exist in distinct strata during the day and that they may undergo extensive diurnal vertical migrations. The similarity of their behaviour to that of certain sonic-scattering layers in the sea, observable with echo-sounding equipment, led Johnson ${ }^{1}$ to suggest that the origin of these layers is biological. Collections by various methods have shown that concentrations of both zooplankton and fishes are associated with these layers. Although much thought has been devoted to the composition of the layers and to the acoustic properties of the animals probably comprising them, attention to the causes of 